\title{
New Insights Towards Catheter-Based Identification of Vulnerable Plaque
}

\author{
Gastón A. Rodríguez-Granillo, Evelyn Regar, Johanness A. Schaar, and Patrick W. Serruys \\ Interventional Cardiology, Thoraxcenter, Erasmus MC, Rotterdam, The Netherlands.
}

Sudden cardiac death or unheralded acute coronary syndromes are common initial manifestations of coronary atherosclerosis and most such events occur at sites of non-flow limiting coronary atherosclerosis. Autopsy data suggests that plaque composition is a key determinant of the propensity of atherosclerotic lesions to provoke clinical events. Most of these events are related to plaque rupture and subsequent thrombotic occlusion at the site of non-flow limiting atherosclerotic lesions in epicardial coronary arteries. Detection of these non-obstructive, lipid rich, high-risk plaques may have an important impact on the prevention of acute myocardial infarction and sudden death. Currently, there are several intravascular tools capable of locally evaluating determinants of plaque vulnerability such as the size of the lipid core, thickness of the fibrous cap, inflammation within the cap and positive remodeling. These new modalities have the potential to provide insights into the pathophysiology of the natural history of coronary plaque by means of prospective studies.

Key words: Vulnerable plaque. Coronary artery disease. Intravascular techniques.

\section{INTRODUCTION}

Cardiovascular disease is a major cause of morbidity and mortality in the western hemisphere. ${ }^{1}$ Despite major advances in the management and diagnosis of patients with coronary artery disease, a large number of victims who are apparently healthy die suddenly without prior symptoms. ${ }^{2,3}$ Most of these events are re-

Correspondence: Dr P.W Serruys

Prof. of Interventional Cardiology

Thoraxcenter, Bd 406. Erasmus MC.

Dr Molewaterplein 40. 3015 GD Rotterdam. The Netherlands.

E-mail: p.w.j.c.serruys@erasmusmc.nl

\section{Nuevas tendencias en la evaluación de la placa vulnerable mediante técnicas de cateterismo}

La muerte súbita y los síndromes coronarios agudos son, frecuentemente, manifestaciones iniciales de la cardiopatía isquémica. Estudios post mórtem han indicado que la composición de las placas ateromatosas es un factor determinante para la predisposición de las lesiones coronarias a la rotura y el subsiguiente evento clínico. La mayor parte de estos eventos está relacionada con la rotura de placas ateromatosas situadas en lesiones hemodinámicamente no significativas. La detección de estas placas no obstructivas, pero ricas en lípidos, podría tener un gran impacto en la prevención del infarto y la muerte súbita. Actualmente, hay diversas técnicas intravasculares capaces de evaluar distintos determinantes de vulnerabilidad coronaria localmente, tales como el tamaño del core lipídico, el grosor y la inflamación de la cápsula fibrosa y el remodelamiento positivo.

Mediante la conducción de estudios prospectivos, estas nuevas modalidades poseen el potencial para proveer in vivo información acerca de la fisiopatología de la historia natural de la aterosclerosis coronaria.

Palabras clave: Placa vulnerable. Enfermedad coronaria. Técnicas intravasculares. lated to plaque rupture and subsequent thrombotic occlusion at the site of non-flow limiting atherosclerotic lesions in epicardial coronary arteries. ${ }^{4,5}$ In addition, silent plaque rupture and its subsequent wound healing accelerate plaque growth and are a more frequent feature in arteries with less severe luminal narrowing. ${ }^{6}$

According to histological studies, plaque composition plays a central role in the pathogenesis of epicardial occlusion, irrespective of the severity of the underlying stenosis. ${ }^{5}$

\section{THE IMAGING TARGET: THE THIN-CAP FIBROATHEROMA}

Recently, retrospective studies have identified morphological and compositional characteristics of 
plaques prone to rupture. ${ }^{7,8}$ This has lead to a new classification of coronary lesions that depicts plaque progression in a more comprehensive manner. ${ }^{8}$

Thin-cap fibro atheroma (TCFA) lesions, the most prevalent predecessor of plaque rupture, are composed of a lipid-rich atheromatous core, a thin $(\leq 65 \mu \mathrm{m})$ fibrous cap with macrophage and lymphocyte infiltration, decreased smooth muscle cell content and expansive remodeling. ${ }^{8,9}$

Detection of these non-obstructive, lipid rich, highrisk plaques may have an important impact on the prevention of acute myocardial infarction and sudden death.

Although angiography can identify obstructive as well as complex lesions, ${ }^{10}$ it is restricted to the visualization of the coronary lumen and is unable to visualize the coronary wall. Thus, features as vessel remodeling or plaque composition are missed. Recently, a post-mortem study evaluated the geometrical aspect of the vessel wall and showed a relationship between local alterations of vessel size and plaque stability. ${ }^{11}$

Currently, there are several intravascular tools capable of locally evaluating determinants of plaque vulnerability such as the size of the lipid core, thickness of the fibrous cap, inflammation within the cap and positive remodelling.

A recent study proposed a critical cap thickness of $<65$ micron based on post mortem histomorphometry. ${ }^{12}$ However, in vivo the threshold for defining a fibrous cap as thin should probably be higher than $65 \mu \mathrm{m}$ for several reasons. First, it is well established that general tissue shrinkage can not be avoided during histologic fixation which implies dehydration processes. ${ }^{13,14}$ Furthermore, circumferential stress at the luminal border of the plaque increases critically when cap thickness is less than approximately $150 \mu \mathrm{m} .^{15}$

We summarize the current status of imaging techniques that have the potential to detect the vulnerable plaque features in vivo and may allow risk stratification in a specific individual and ultimately guide systemic and local preventive strategies..$^{9,16-20}$

\section{INTRAVASCULAR ULTRASOUND}

Gray scale IntraVascular UltraSound (IVUS) is an invasive diagnostic tool that provides a real-time, highresolution, tomographic view of coronary arteries. It thereby enables the assessment of morphology, severity and extension of coronary plaque.

IVUS is currently the only imaging modality that can provide in vivo information regarding temporal changes in the atherosclerotic plaque size. ${ }^{21}$

Qualitative plaque characterization is based on the echogenicity of the received ultrasound signal, whereas echolucent zones reflect lipid-rich tissue and highly reflective structures with dorsal shadowing calcified tissue. Nevertheless, plaque characterization through visual interpretation of gray-scale IVUS is imprecise, specially when assessing heterogeneous, lipidrich plaques. ${ }^{22}$

Axial resolution is limited to $100-200 \mu \mathrm{m}$ thus impairing the ability of detecting thin fibrous caps. Notwithstanding, for the aforementioned reasons, we believe that the threshold for defining a fibrous cap as thin should be higher than $65 \mu \mathrm{m}$.

The detection of vulnerable plaques by IVUS is mainly based on a series of case reports. ${ }^{23-26}$ These reports describe morphologic features of already ruptured plaques but not the prospective detection of rupture-prone plaques. Nevertheless, one prospective study showed that large eccentric plaques containing an echolucent zone by IVUS were found to be at increased risk of instability even though the lumen area was preserved at the time of initial study. ${ }^{27}$

\section{ROLE OF VESSEL REMODELING}

Vascular remodeling was described by Glagov as a compensatory enlargement of the coronary arteries in response to an increase in plaque area. ${ }^{28}$ Several studies showed an increase level of inflammatory marker levels, larger lipid cores and pronounced medial thinning in positive remodeled vessels. ${ }^{11,29,30}$ This concept has further evolved to a dynamic theory

TABLE. Comparison of Catheter-Based Techniques for Detection of Individual Features of Vulnerable Plaque

\begin{tabular}{lccc}
\hline Technique & Thin-Cap Detection & Inflammation & Lipid Core \\
\hline Intravascular ultrasound & + & - & + \\
Echogenecity & - & - & + \\
Palpography & ++ & ++ & + \\
Virtual histology & ++ & - & ++ \\
Optical coherence tomography & +++ & +++ & + \\
Thermography & - & - & - \\
Angioscopy & - & - & ++ \\
Intravascular MRI & - & - & + \\
Spectroscopy & - & - & ++ \\
\end{tabular}


Figure 1. IVUS echogenecity: the adventitia is defined as tissue outside the external elastic membrane. For all nonshadowed adventitia pixels, the mean value and standard deviation are calculated. To observe the suitability, a normal distribution curve based on the same mean and standard deviation histogram is created. Hypoechogenic areas are colored red and hyperechogenic areas green.
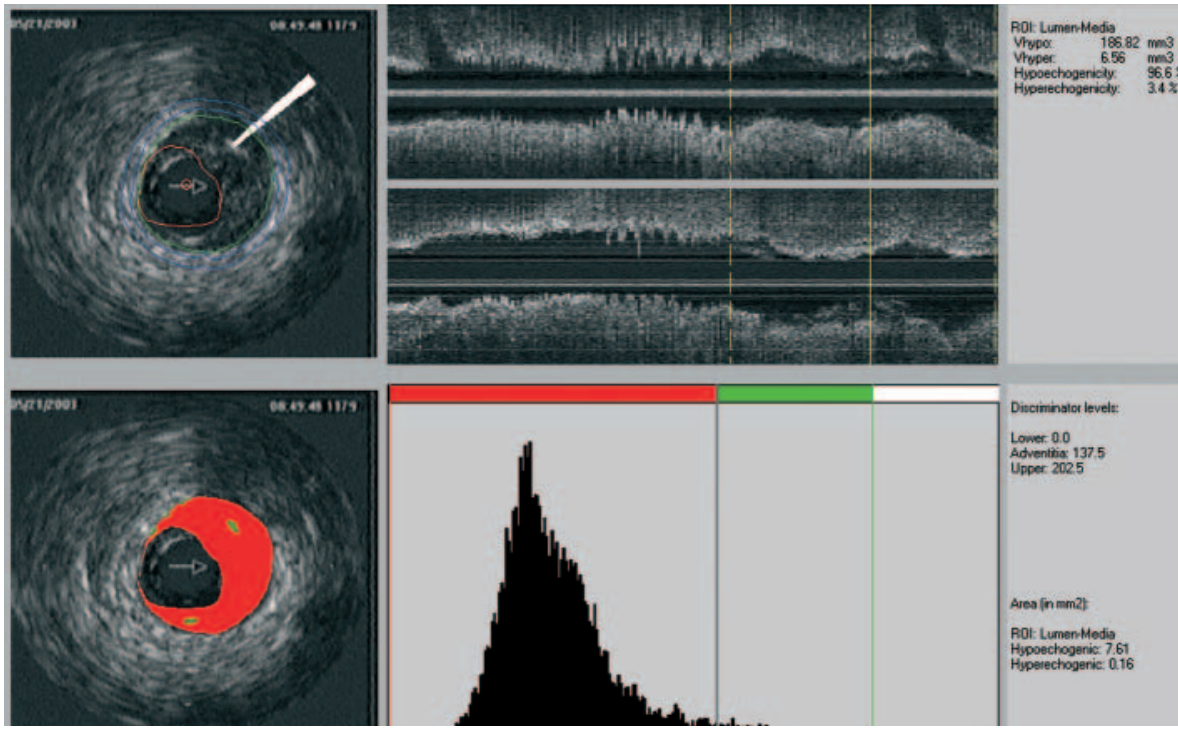

where vessels may also shrink in response to plaque growth. ${ }^{31}$ This remodeling modality has been related to a more stable phenotype and clinical presentation. ${ }^{11,29,32,33}$ Recently, the relationship between vascular remodeling and plaque composition was assessed using IVUS. ${ }^{34-36}$ In these studies, the remodeling index for soft lesions was significantly higher than those for fibrous/mixed and calcified lesions. ${ }^{34-36}$ It is noteworthy though, that most studies evaluating this phenomenon are of cross sectional design. Since atherosclerosis is usually a diffuse disease, finding a fully non-diseased reference is not guaranteed. Therefore, the early presence of remodeling in the reference site can't be ruled out.

\section{QUANTITATIVE IVUS ECHOGENICITY ASSESSMENT}

We recently developed a computer-aided, gray-scale value, analysis program for plaque characterization. ${ }^{37}$ Based on the mean gray level (brightness) of the adventitia, plaque is classified as more (hyperechogenic) or less bright (hypoechogenic) in relation to the adventitia (Figure 1). The percentage of hypoechogenic plaque is calculated for the entire region of interest and for slices with significant plaque. In the carotid circulation, plaque echogenicity, measured noninvasively, has been related to the histological components of plaque. ${ }^{38-41}$ Furthermore, carotid plaque echolucency (low echogenicity) was associated with future neurological events. ${ }^{42-44}$ IVUS-based plaque characterization in the coronary circulation requires invasive assessment and has been less extensively studied. A recent study showed that treatment with atorvastatin resulted in quantifiable changes in coronary plaque echogenicity, compatible with changes in plaque composition. ${ }^{45}$ These findings offered a potential explana- tion for the clinical efficacy of statins despite only modest effects on plaque volume. ${ }^{21,46}$ Both ex vivo and clinical studies that will provide validation data about the technique are currently in progress.

\section{Intravascular Ultrasound Elastography and Palpography}

An important patho-morphologic feature of vulnerable plaque is

the eccentric accumulation of a lipid-rich necrotic core within the vessel wall, separated from the lumen by a thin fibrous cap. This observation led to the hypothesis that vulnerable lesions might have mechanical properties that differ from those of chronic stable lesions. Intravascular ultrasound elastography and palpography are techniques that allow the assessment of local mechanical tissue properties..$^{19,47}$

At a defined pressure, soft tissue (lipid-rich) components will deform more than hard tissue components (fibrous-calcified). ${ }^{48}$ In coronaries, the tissue of interest is the vessel wall, whereas the blood pressure with its physiologic, systolic and diastolic changes during the heart cycle is used as the excitation force. Images obtained at different pressure levels are compared to determine the local tissue compression. The radial strain in the tissue is calculated by cross-correlation techniques on the radio frequency signal and can be displayed as a colour-coded image. ${ }^{48}$ The sensitivity and specificity to detect vulnerable plaques has recently been assessed in post-mortem human coronary arteries where vulnerable plaques were detected with a sensitivity of $88 \%$ and a specificity of $89 \%$ (Figure 2). ${ }^{19}$ In addition to ex-vivo studies, this technique has also been tested in vivo, where palpography detected a high incidence of deformable plaques in acute coronary syndrome (ACS) patients. 


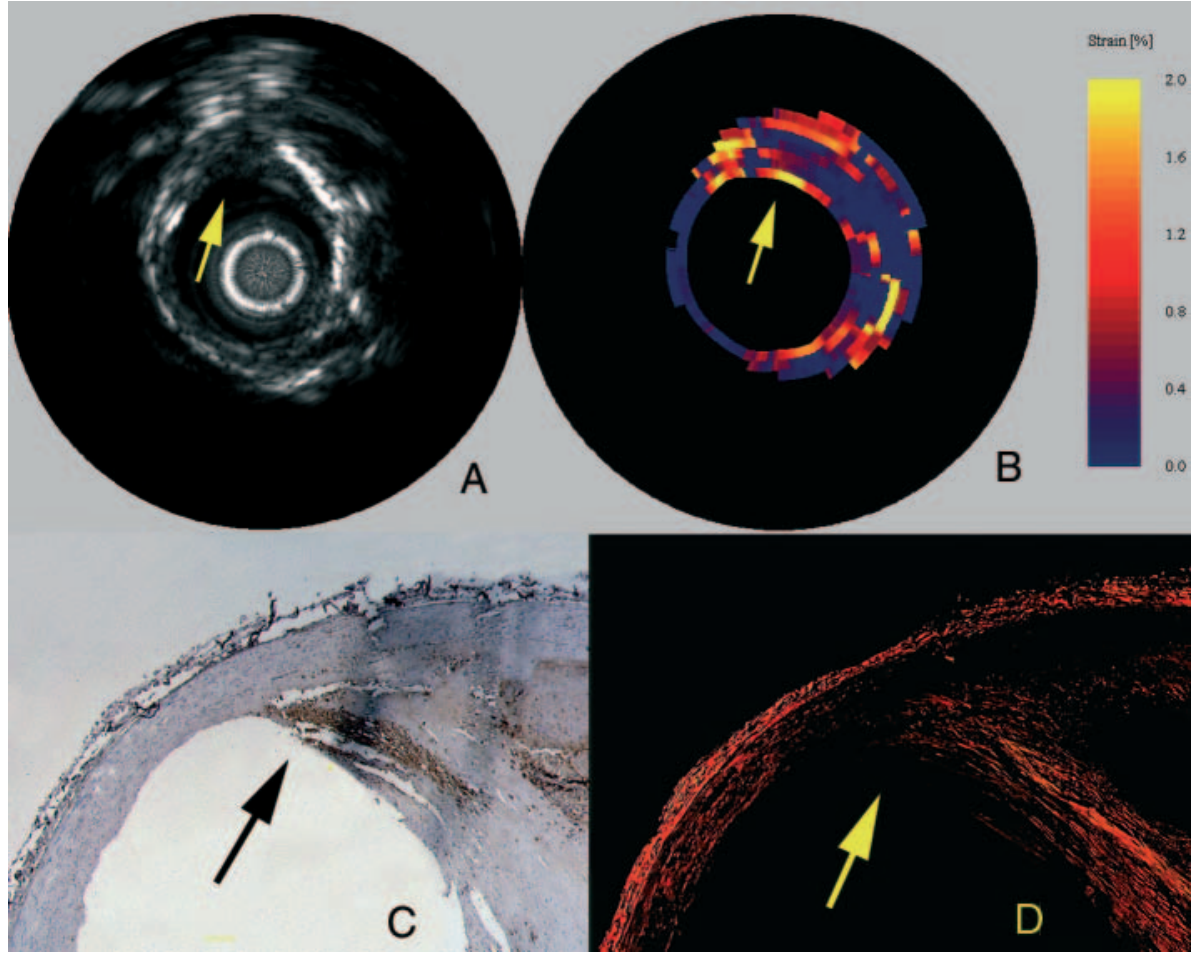

Figure 2. Vulnerable plaque marked in IVUS (A), elastogram (B), macrophage staining (C), and collagen staining (D). In the elastogram, a vulnerable plaque is indicated by a high strain on the surface. In the corresponding histology, a high amount of macrophages $(C)$ is visible with a thin cap (D) and a lipid pool (LP). (Schaar et al. Circulation. 2003;108:2636.)
Furthermore, the number of highly deformable lesions was correlated to the clinical presentation and levels of C-reactive protein. ${ }^{47}$

The main limitation of the technique is that it depends on the quality and stability of the coronary pressure signal. Accordingly, it might be disturbed by high heart rates and rhythm disturbances.

\section{Virtual Histology}

Gray-scale IVUS is of limited value for identification of specific plaque components. ${ }^{49}$ Calcified and dense fibrous tissues usually are highly echo-reflective thus calcified areas are commonly overestimated. On the other hand, low echo-reflectance plaques are considered "soft" or lipid-rich. However, the accuracy of gray-scale IVUS for discriminating lipid from fibrous tissue is limited since in addition to large amounts of extracellular lipids (low echo-reflective areas), the lipid core contains cholesterol crystals, necrotic debris and microcalcifications (highly echoreflective areas). ${ }^{8}$

A recently introduced technique (IVUS-Virtual Histology ${ }^{\mathrm{TM}}$ [IVUS-VH], Volcano Therapeutics, Rancho Cordova, CA) that uses the substrate (frequency domain analysis) of the IVUS radiofrequency (RF) data rather than the envelope (amplitude), has demonstrated its potential to provide an objective and accurate assessment of coronary plaque composition in studies of explanted human coronary segments. ${ }^{20}$
IVUS-VH uses spectral analysis of IVUS radiofrequency data to construct tissue maps that classify plaque into four major components. In preliminary in vitro studies, four histological plaque components (fibrous, fibrolipidic, lipid core, and calcium) were correlated with a specific spectrum of the radiofrequency signal. ${ }^{20,50}$ These different plaque components were assigned color codes. Calcified, fibrous, fibrolipidic, and lipid core regions were labeled white, green, greenishyellow, and red respectively (Figure 3 ).

IVUS studies have failed to conclusively demonstrate regression in plaque burden over time. ${ }^{21,51,52}$ IVUS-VH has, though, the potential to follow the progression of the disease not only with regards to its volume, but to its composition as well..$^{53}$ Moreover, this tool could also be helpful in evaluating the effect of both conventional and emerging therapeutic interventions.

With regards to vulnerable plaque detection, IVUS$\mathrm{VH}$ allows an accurate and quantitative assessment of 2 of the main features of the TCFA: lipid core and positive remodeling.

A main limitation of this technique is its inability to detect thin fibrous caps. However, as aforementioned we believe that the threshold for defining a thin fibrous cap should be higher than $65 \mu \mathrm{m}$.

\section{Optical Coherence Tomography}

Optical coherence tomography (OCT) is an imaging technique that allows high-resolution (axial re- 
Figure 3. Serial histological sectioning of a coronary vessel. The middle and below panels depict the cross-correlation with Virtual HistologyTM and gray-scale IVUS respectively. Calcified, fibrous, fibrolipidic and lipid core regions are labeled white, green, greenish-yellow and red respectively.

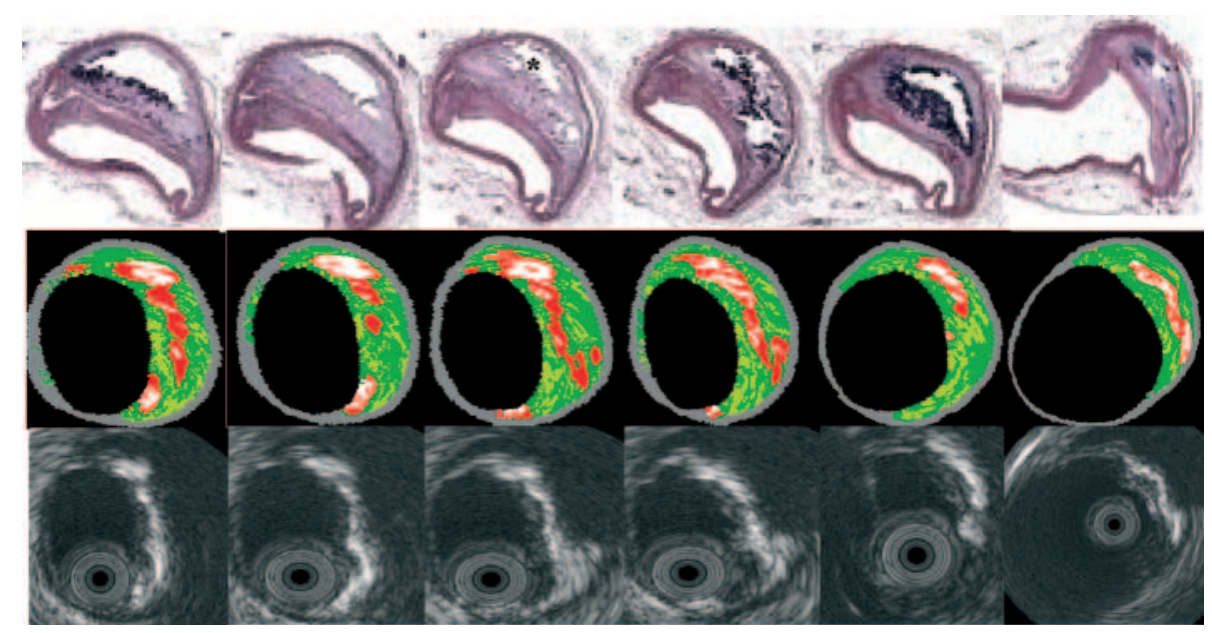

solution of $15 \mu \mathrm{m})$ imaging in biological systems. ${ }^{54}$ Accordingly, OCT has the capacity to allow in vivo, real time visualization of a thin fibrous cap. OCT imaging is based on low coherence near infrared light that is emitted by a superluminescent diode. A center wave length around $1300 \mathrm{~nm}$ is used since it minimizes the energy absorption in the light beam caused by protein, water, haemoglobin, and lipids. The light waves are reflected by the internal microstructures within biological tissues as a result of their differing optical indices.

Animal and Post-mortem studies demonstrated the accuracy of OCT in comparison to histology. ${ }^{55-57}$ These studies showed that OCT can detect both normal and pathologic artery structures (Figure 4) $.^{57} \mathrm{Re}-$ cent in vivo data have shown that OCT can differentiate different plaque types and suggested the possibility of detection of macrophages in atherosclerotic plaques. ${ }^{58,59}$

In our experience, TCFA with low-reflecting necrotic cores covered by highly reflecting thin (mean 50 $\mu \mathrm{m})$ fibrous caps cap can be visualized in patients scheduled for percutaneous coronary intervention (PCI). ${ }^{60}$

The high resolution of OCT offers the potential to detect TCFA in living patients. ${ }^{59,60}$ OCT imaging, however, is limited by the relative shallow penetration depth that hampers imaging of the entire vessel wall in medium and large vessels large vessels, and the need to clear the artery from blood during imaging causing transient ischemia of the studied region.

\section{Intravascular Thermography}

The rationale to measure vascular temperature is based on the observation that atherosclerosis is accompanied by inflammation. Vulnerable plaques have been associated with increased macrophage activity, metabolism and inflammation. ${ }^{61}$ Based on these findings the hypothesis was generated that these "activated" macrophages produce thermal energy, which might be detected on the surface of these atherosclerotic lesions. Infrared and contactsensor thermographies are the most important invasive methods (Figure 5). The contact thermographic methods seem to be the most feasible at the present time, mainly due to the difficulties of infrared radiation to penetrate the flowing blood to detect vessel wall temperature. A small study of 19 patients that included patients with stable angina, unstable angina, and with acute myocardial infarction reported temperature heterogeneity in human atherosclerotic coronary plaques. ${ }^{62}$ Intracoronary temperature was assessed using a dedicated catheter. In most coronary segments with atherosclerotic plaques a rise in temperature was seen as compared to coronary segments with a normal vessel wall. Temperature differences between an atherosclerotic plaque and a normal vessel wall increased progressively from patients with stable angina to patients with acute myocardial infarction with a maximum temperature difference to the background temperature of $1.5 \pm 0.7^{\circ} \mathrm{C}$. However, there are somewhat conflicting published and unpublished reports with other thermography devices (circular basket or self expanding arms) that have documented a much lower heterogeneity of temperature distribution. The most likely explanation for this discrepancy in temperature observations might be related to the difference in catheter design and the way coronary flow is affected.

These preliminary findings about the thermal status of atherosclerotic plaques seem promising. However, accurate temperature evaluation requires direct contact of the thermistors with the vessel wall, carrying the potential risk of endothelial damage. In addition, the cooling effect caused by blood flow may hamper data interpretation. ${ }^{63}$ 


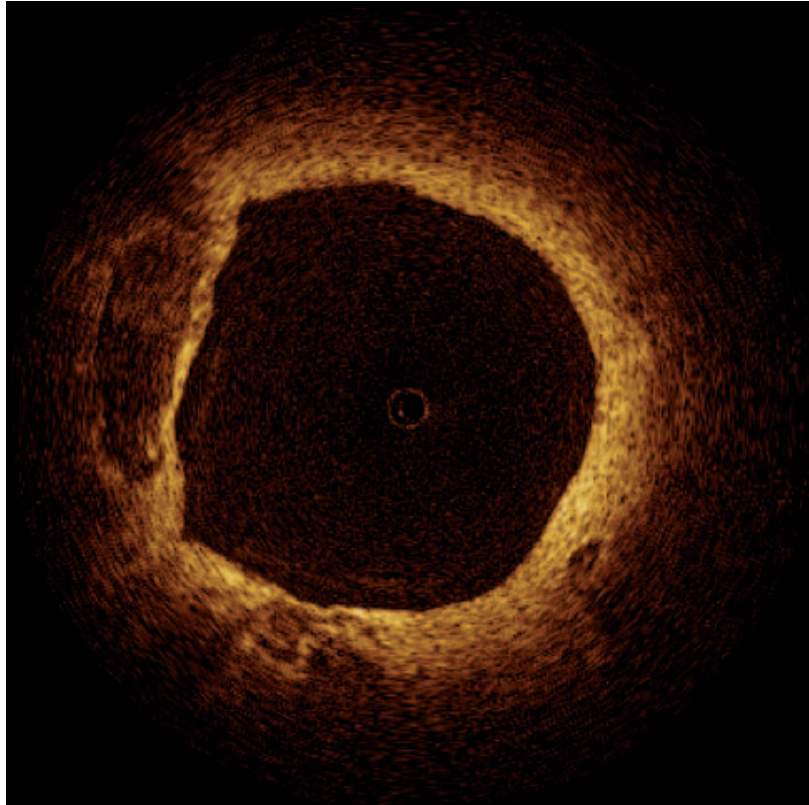

Figure 4. Optical coherence tomography of a non-flow limiting lesion showing a "swiss-cheese" vessel wall suggestive of a thin-cap fibroatheroma.

\section{Angioscopy}

This technique allows real-time direct visualization of coronary plaques (Figure 6). Ex vivo validation of angioscopy was performed by Thieme et al, who compared angioscopic observations with histologic samples obtained by coronary atherectomy. In this study, yellow plaques were related to atheromatous lesions. ${ }^{64}$ These findings were confirmed in clinical studies, where lipid-rich, rupture-prone plaques were easily detected by angioscopy as yellow plaques, and found more commonly in acute coronary syndromes. ${ }^{65}$ Furthermore, angioscopy has shown in- triguing results in the prediction of acute coronary syndromes. ${ }^{65}$

Despite these encouraging findings, this technique examines solely the luminal surface of the intima. Thus, key TCFA features such as thickness of the cap, lipid core content, and remodelling can not be assessed. In addition, blood must be cleared away from the view causing transient ischemia of the studied region.

\section{RAMAN SPECTROSCOPY}

Raman spectroscopy is a technique that can characterize the chemical composition by means of the Raman effect. ${ }^{66}$ This effect is created when incident light excites molecules in a tissue sample, which scatter light in a different wave length. This change in wave length called the "Raman effect" is dependent on the chemical components of the tissue sample. Thus, Raman spectroscopy can provide quantitative information about molecular composition of a sample. ${ }^{67}$ The spectra obtained require post-processing to differentiate between plaque components (Figure 7). In vitro studies have demonstrated that diagnostic algorithms allow the discrimination of coronary arterial tissue in 3 categories: non-atherosclerotic, non-calcified and calcified plaques. ${ }^{67}$

The main limitations of the technique are the inability to provide geometrical information, the narrow penetration depth (1.0 to $1.5 \mathrm{~mm}$ ) and the absorbance of the laser light by the blood.

\section{INTRAVASCULAR MAGNETIC RESONANCE IMAGING}

Intravascular magnetic resonance imaging (MRI) is another potential approach to determine plaque composition based on the diffusion properties of the

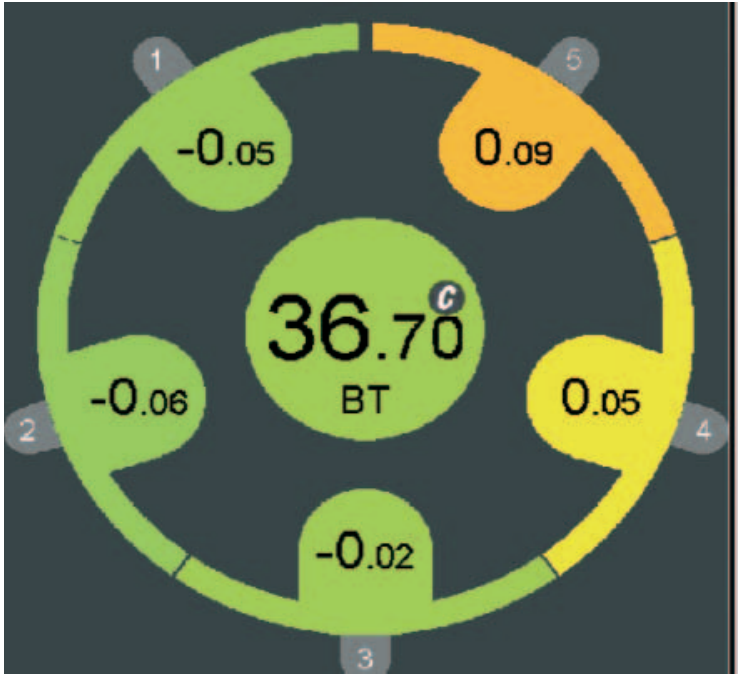

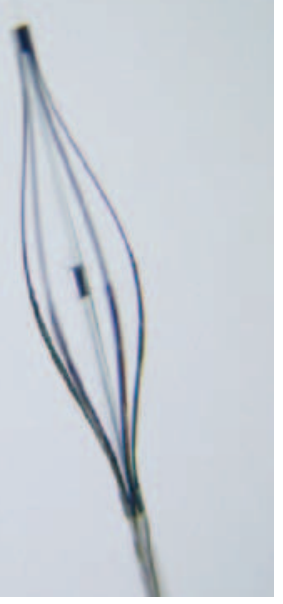

Figure 5. Dedicated thermography catheter with 5 thermistors in contact to the vessel wall showing significant heterogeneity in the measurements compatible with increased macrophage activity, metabolism, and inflammation. 


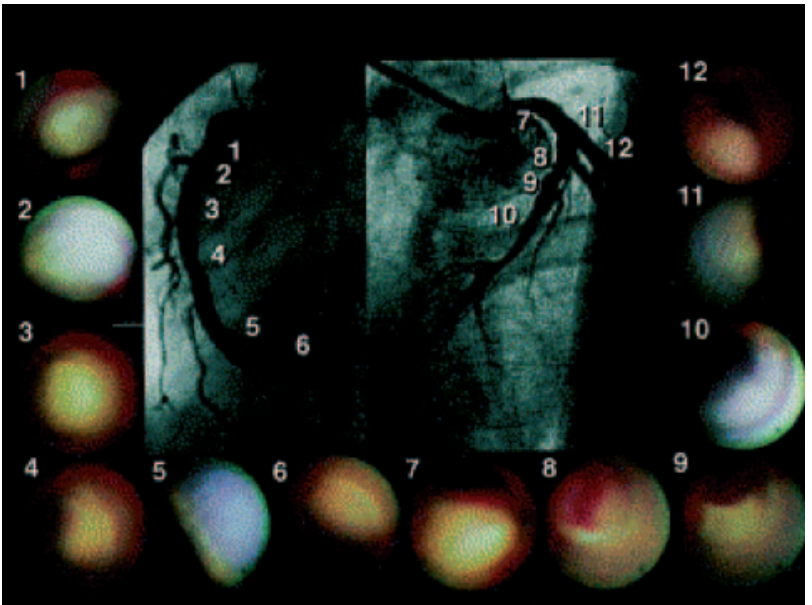

Figure 6. Patient with anterior myocardial infarction. Angioscopic images of the culprit lesion ( 8 and 9 ) and of all the yellow plaques in the non-culprit segments are presented. Thrombus was detected over the yellow plaque in the culprit segment. (Asakura et al. J Am Coll Cardiol. 2001;37:1284-8.)

analyzed tissue. MRI can determine the presence of lipid within the arterial wall. Current technology for intravascular MRI consists of a self-contained MRI probe that allows sequential scanning of different vessels sectors. The lipid-content within a sector is determined and the data is displayed color-coded (yellow corresponds to high lipid content within the region of interest, blue to low lipid-content [Figure 8]).

The intravascular MRI system has been evaluated in ex-vivo human carotid tissue, aortic tissue and coronary arteries to correlate MRI findings with histology. In ex vivo aortic studies the MRI correctly predicted the histologic results in 15 of 16 aortic cases, and in ex-vivo coronary arteries 16 of 18 lesions were correctly predicted, including the diagnosis of 3 thin cap fibroatheromas. ${ }^{68,69}$ In vivo feasibility is currently under investigation in a multi-center trial.

\section{FUTURE PERSPECTIVES}

It has previously been shown that a multifocal instability process is present in acute coronary syndromes. ${ }^{26,70}$ Rioufol et al demonstrated in ACS patients that at least one plaque rupture is found away from the culprit lesion in $80 \%$ of the patients, away from the culprit artery in $71 \%$ and in the 2 non-culprit arteries in $12.5 \% .^{26}$

The large number of high-risk lesions found throughout the coronary tree by means of angiography, ${ }^{71}$ angioscopy,${ }^{70}$ IVUS,${ }^{26}$ and palpography ${ }^{47}$ in addition to the unpredictability of the natural history of such lesions and the uncertainty about if vulnerable plaque characteristics might subsequently lead to fatal or non-fatal is-

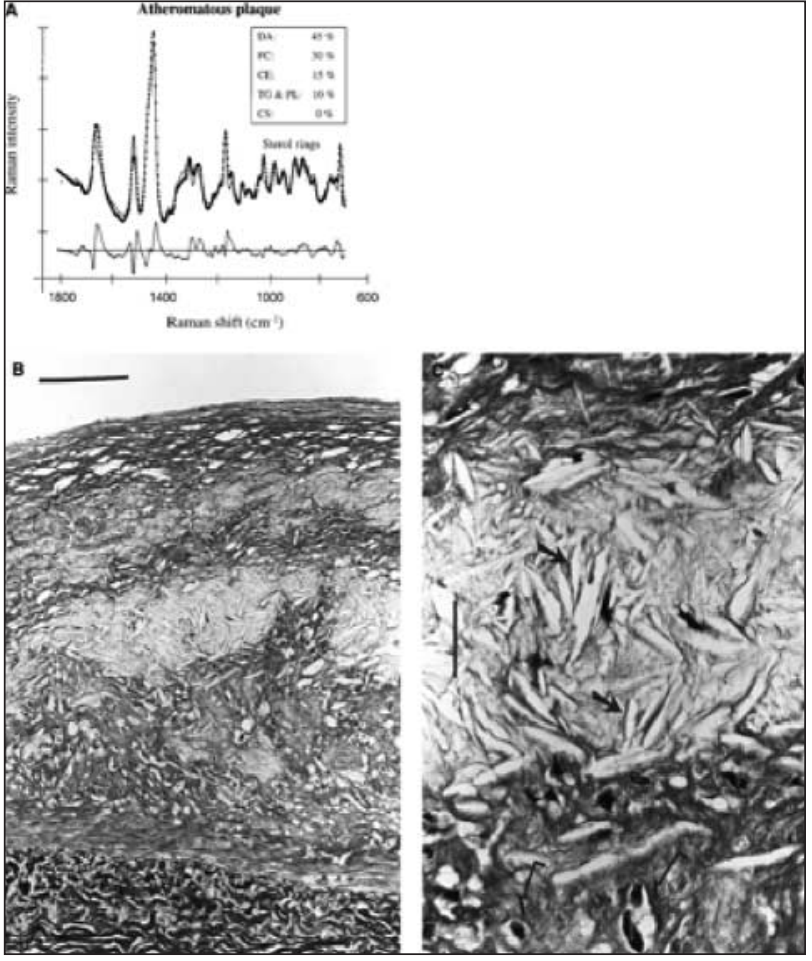

Figure 7. Raman spectrum from atheromatous plaque and model fit (A). The increase of the relative weights of the chemical components FC and CE, as compared with intimal fibroplasia, corresponds to the presence of an atheromatous core under a fibrous cap (B, bar indicates $100 \mu \mathrm{m})$. An abundance of lipid-laden foam cells (open arrows) and FC crystal clefts (solid arrows) is visible in the atheromatous core (C, bar indicates $25 \mu \mathrm{m}$ ). (Romer et al. Circulation. 1998;97:878-85.)

chemic events, suggests that potential local preventive strategies could not be cost-effective.

However, high-risk "yellow" plaques identified in stable patients by angioscopy have been found predictors of ischemic events. ${ }^{65}$ Accordingly, a systemic approach including intensive statin therapy could be a reasonable approach to "cool-down" the inflammatory burden.

Although enormously promising, catheter-based techniques need more extensive validation and an appropriate vulnerable plaque model is yet to be developed. In addition, these techniques interrogate the coronary arteries in a localized manner, whereas inflammation is distributed throughout the whole coronary tree. ${ }^{72}$

These new modalities have the potential to provide insights into pathophysiology in studies of the natural history of coronary plaque. Furthermore, they may provide surrogate endpoints. Finally, the combination between novel imaging techniques and the assessment of circulating biomarkers could have a potential role in patient risk stratification and eventually offer the potential to allow the effect of conventional and emer- 


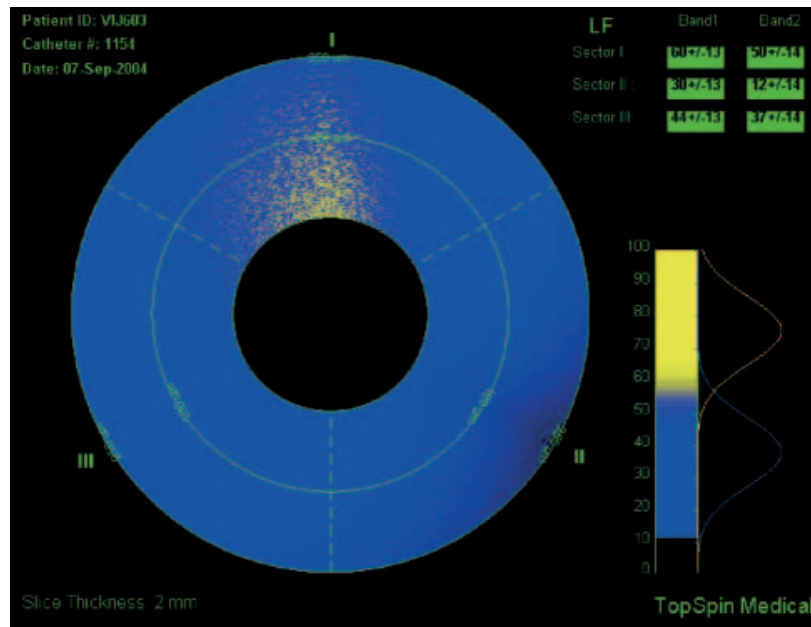

Figure 8. Intravascular MRI of a coronary vessel where plaque composition is colo-coded: yellow corresponds to high lipid content within the region of interest, blue to low lipid (fibrotic) content.

ging pharmacologic interventions with novel mechanisms of action as well. ${ }^{53}$

\section{REFERENCES}

1. Yusuf S, Reddy S, Ounpuu S, Anand S. Global burden of cardiovascular diseases: Part II: variations in cardiovascular disease by specific ethnic groups and geographic regions and prevention strategies. Circulation. 2001;104:2855-64.

2. Kannel WB, Doyle JT, McNamara PM, Quickenton P, Gordon T. Precursors of sudden coronary death. Factors related to the incidence of sudden death. Circulation. 1975;51:606-13.

3. Falk E, Shah PK, Fuster V. Coronary plaque disruption. Circulation. 1995;92:657-71.

4. Ambrose JA, Tannenbaum MA, Alexopoulos D, Hjemdahl-Monsen CE, Leavy J, Weiss M, et al. Angiographic progression of coronary artery disease and the development of myocardial infarction. J Am Coll Cardiol. 1988;12:56-62.

5. Little WC, Constantinescu M, Applegate RJ, Kutcher MA, Burrows MT, Kahl FR, et al. Can coronary angiography predict the site of a subsequent myocardial infarction in patients with mildto-moderate coronary artery disease? Circulation. 1988;78:115766.

6. Burke AP, Kolodgie FD, Farb A, Weber DK, Malcom GT, Smialek J, et al. Healed plaque ruptures and sudden coronary death: evidence that subclinical rupture has a role in plaque progression. Circulation. 2001;103:934-40.

7. Davies MJ, Richardson PD, Woolf N, Katz DR, Mann J. Risk of thrombosis in human atherosclerotic plaques: role of extracellular lipid, macrophage, and smooth muscle cell content. Br Heart J. 1993;69:377-81.

8. Virmani R, Kolodgie FD, Burke AP, Farb A, Schwartz SM. Lessons from sudden coronary death: a comprehensive morphological classification scheme for atherosclerotic lesions. Arterioscler Thromb Vasc Biol. 2000;20:1262-75.

9. Schaar JA, Muller JE, Falk E, Virmani R, Fuster V, Serruys $\mathrm{PW}$, et al. Terminology for high-risk and vulnerable coronary artery plaques. Report of a meeting on the vulnerable plaque, June 17 and 18, 2003, Santorini, Greece. Eur Heart J. 2004;25: 1077-82.

10. Ambrose JA. Prognostic implications of lesion irregularity on coronary angiography. J Am Coll Cardiol. 1991;18:675-6.

11. Pasterkamp G, Schoneveld AH, van der Wal AC, Haudenschild $\mathrm{CC}$, Clarijs RJ, Becker AE, et al. Relation of arterial geometry to luminal narrowing and histologic markers for plaque vulnerability: the remodeling paradox. J Am Coll Cardiol. 1998;32:655-62.

12. Burke AP, Farb A, Malcom GT, Liang YH, Smialek J, Virmani R. Coronary risk factors and plaque morphology in men with coronary disease who died suddenly. N Engl J Med. 1997;336: 1276-82.

13. MKW L. A critical appraise of the effects of fixation, dehydration and embedding of cell volume. In: Revel JP, Barnard T, Haggis $\mathrm{GH}$, editors. The science of biological specimen preparation for microscopy and microanalysis. Scanning electron microscopy, AMF O'Hare, 1984;IL 60666:pp.61-70.

14. Boyde AJS, Tamarin A. Dimensional changes during specimen preparation for scanning electron microscopy. Scan Electron Microsc. 1977:507-18.

15. Loree HM, Kamm RD, Stringfellow RG, Lee RT. Effects of fibrous cap thickness on peak circumferential stress in model atherosclerotic vessels. Circ Res. 1992;71:850-8.

16. Hoye A, Lemos PA, Arampatzis CA, Saia F, Tanabe K, Degertekin $\mathrm{M}$, et al. Effectiveness of sirolimus-eluting stent implantation for coronary narrowings $<50 \%$ in diameter. Am J Cardiol. 2004; 94:112-4.

17. Jang IK, Bouma BE, Kang DH, Park SJ, Park SW, Seung KB, et al. Visualization of coronary atherosclerotic plaques in patients using optical coherence tomography: comparison with intravascular ultrasound. J Am Coll Cardiol. 2002;39:604-9.

18. Moreno PR, Muller JE. Detection of high-risk atherosclerotic coronary plaques by intravascular spectroscopy. J Interv Cardiol. 2003; 16:243-52.

19. Schaar JA, de Korte CL, Mastik F, Strijder C, Pasterkamp G, Boersma E, et al. Characterizing vulnerable plaque features with intravascular elastography. Circulation. 2003;108:2636-41.

20. Nair A, Kuban BD, Tuzcu EM, Schoenhagen P, Nissen SE, Vince DG. Coronary plaque classification with intravascular ultrasound radiofrequency data analysis. Circulation. 2002;106:22006.

21. Nissen SE, Tuzcu EM, Schoenhagen P, Brown BG, Ganz P, Vogel RA, et al. Effect of intensive compared with moderate lipidlowering therapy on progression of coronary atherosclerosis: a randomized controlled trial. JAMA. 2004;291:1071-80.

22. Peters RJ, Kok WE, Havenith MG, Rijsterborgh H, van der Wal AC, Visser CA. Histopathologic validation of intracoronary ultrasound imaging. J Am Soc Echocardiogr. 1994;7:230-41.

23. Ge J, Haude M, Gorge G, Liu F, Erbel R. Silent healing of spontaneous plaque disruption demonstrated by intracoronary ultrasound. Eur Heart J. 1995;16:1149-51.

24. Jeremias A, Ge J, Erbel R. New insight into plaque healing after plaque rupture with subsequent thrombus formation detected by intravascular ultrasound. Heart. 1997;77:293.

25. Ge J, Chirillo F, Schwedtmann J, Gorge G, Haude M, Baumgart $\mathrm{D}$, et al. Screening of ruptured plaques in patients with coronary artery disease by intravascular ultrasound. Heart. 1999;81:621-7.

26. Rioufol G, Finet G, Ginon I, Andre-Fouet X, Rossi R, Vialle E, et al. Multiple atherosclerotic plaque rupture in acute coronary syndrome: a three-vessel intravascular ultrasound study. Circulation. 2002;106:804-8.

27. Yamagishi M, Terashima M, Awano K, Kijima M, Nakatani S, Daikoku S, et al. Morphology of vulnerable coronary plaque: insights from follow-up of patients examined by intravascular ultrasound before an acute coronary syndrome. J Am Coll Cardiol. 2000;35:106-11.

28. Glagov S, Weisenberg E, Zarins CK, Stankunavicius R, Kolettis GJ. Compensatory enlargement of human atherosclerotic coronary arteries. N Engl J Med. 1987;316:1371-5. 
29. Varnava AM, Mills PG, Davies MJ. Relationship between coronary artery remodeling and plaque vulnerability. Circulation. 2002;105:939-43.

30. Burke AP, Kolodgie FD, Farb A, Weber D, Virmani R. Morphological predictors of arterial remodeling in coronary atherosclerosis. Circulation. 2002;105:297-303.

31. Pasterkamp G, Wensing PJ, Post MJ, Hillen B, Mali WP, Borst C. Paradoxical arterial wall shrinkage may contribute to luminal narrowing of human atherosclerotic femoral arteries. Circulation. 1995;91:1444-9.

32. Smits PC, Pasterkamp G, Quarles van Ufford MA, Eefting FD, Stella PR, de Jaegere PP, et al. Coronary artery disease: arterial remodelling and clinical presentation. Heart. 1999;82:461-4.

33. Nakamura M, Nishikawa H, Mukai S, Setsuda M, Nakajima K, Tamada $\mathrm{H}$, et al. Impact of coronary artery remodeling on clinical presentation of coronary artery disease: an intravascular ultrasound study. J Am Coll Cardiol. 2001;37:63-9.

34. Tauth J, Pinnow E, Sullebarger JT, Basta L, Gursoy S, Lindsay $\mathrm{J} \mathrm{Jr}$, et al. Predictors of coronary arterial remodeling patterns in patients with myocardial ischemia. Am J Cardiol. 1997;80: $1352-5$.

35. Sabate M, Kay IP, de Feyter PJ, van Domburg RT, Deshpande NV, Ligthart JM, et al. Remodeling of atherosclerotic coronary arteries varies in relation to location and composition of plaque. Am J Cardiol. 1999;84:135-40.

36. Fuessl RT, Kranenberg E, Kiausch U, Baer FM, Sechtem U, Hopp HW. Vascular remodeling in atherosclerotic coronary arteries is affected by plaque composition. Coron Artery Dis. 2001;12:91-7.

37. de Winter SA HI, Hamers R, de Feyter PJ, Serruys PWC, Roelandt JRTC, Bruining N. Computer assisted three-dimensional plaque characterization in ultracoronary ultrasound studies. Comput Cardiol. 2003;30:73-6.

38. el-Barghouty NM, Levine T, Ladva S, Flanagan A, Nicolaides A. Histological verification of computerised carotid plaque characterisation. Eur J Vasc Endovasc Surg. 1996;11:414-6.

39. Gronholdt ML, Nordestgaard BG, Wiebe BM, Wilhjelm JE, Sillesen $\mathrm{H}$. Echo-lucency of computerized ultrasound images of carotid atherosclerotic plaques are associated with increased levels of triglyceride-rich lipoproteins as well as increased plaque lipid content. Circulation 1998;97:34-40.

40. Rasheed Q, Dhawale PJ, Anderson J, Hodgson JM. Intracoronary ultrasound-defined plaque composition: computer-aided plaque characterization and correlation with histologic samples obtained during directional coronary atherectomy. Am Heart J. 1995; 129:631-7.

41. Prati F, Arbustini E, Labellarte A, dal Bello B, Sommariva L, Mallus MT, et al. Correlation between high frequency intravascular ultrasound and histomorphology in human coronary arteries. Heart. 2001;85:567-70.

42. Polak JF, Shemanski L, O'Leary DH, Lefkowitz D, Price TR, Savage $\mathrm{PJ}$, et al. Hypoechoic plaque at US of the carotid artery: an independent risk factor for incident stroke in adults aged 65 years or older. Cardiovascular Health Study. Radiology. 1998;208:64954.

43. Gronholdt ML, Nordestgaard BG, Schroeder TV, Vorstrup S, Sillesen $\mathrm{H}$. Ultrasonic echolucent carotid plaques predict future strokes. Circulation. 2001;104:68-73.

44. Mathiesen EB, Bonaa KH, Joakimsen O. Echolucent plaques are associated with high risk of ischemic cerebrovascular events in carotid stenosis: the tromso study. Circulation. 2001;103:2171-5.

45. Schartl M, Bocksch W, Koschyk DH, Voelker W, Karsch KR, Kreuzer J, et al. Use of intravascular ultrasound to compare effects of different strategies of lipid-lowering therapy on plaque volume and composition in patients with coronary artery disease. Circulation. 2001;104:387-92.

46. Cannon CP, Braunwald E, McCabe CH, Rader DJ, Rouleau JL, Belder R, et al. Intensive versus moderate lipid lowering with statins after acute coronary syndromes. N Engl J Med. 2004;350: 1495-504
47. Schaar JA, Regar E, Mastik F, McFadden EP, Saia F, Disco C, et al. Incidence of high-strain patterns in human coronary arteries: assessment with three-dimensional intravascular palpography and correlation with clinical presentation. Circulation. 2004;109: 2716-9.

48. de Korte CL, van der Steen AF, Cespedes EI, Pasterkamp G. Intravascular ultrasound elastography in human arteries: initial experience in vitro. Ultrasound Med Biol. 1998;24:401-8.

49. Peters RJ, Kok WE, Rijsterborgh H, van Dijk M, Koch KT, Piek $\mathrm{JJ}$, et al. Reproducibility of quantitative measurements from intracoronary ultrasound images. Beat-to-beat variability and influence of the cardiac cycle. Eur Heart J. 1996;17:1593-9.

50. Moore MP, Spencer T, Salter DM, Kearney PP, Shaw TR, Starkey IR, et al. Characterisation of coronary atherosclerotic morphology by spectral analysis of radiofrequency signal: in vitro intravascular ultrasound study with histological and radiological validation. Heart. 1998;79:459-67.

51. von Birgelen C, Hartmann M, Mintz GS, Baumgart D, Schmermund A, Erbel R. Relation between progression and regression of atherosclerotic left main coronary artery disease and serum cholesterol levels as assessed with serial long-term $(\geq 12$ months) follow-up intravascular ultrasound. Circulation. 2003; 108:2757-62.

52. Takagi T, Yoshida K, Akasaka T, Hozumi T, Morioka S, Yoshikawa J. Intravascular ultrasound analysis of reduction in progression of coronary narrowing by treatment with pravastatin. Am J Cardiol.1997;79:1673-6.

53. Rodriguez-Granillo GA, Aoki J, Ong ATL, Valgimigli M, van Mieghem CAG, Regar E, et al. Methodological considerations and approach to cross-technique comparisons using in vivo coronary plaque characterization based on intravascular ultrasound radiofrequency data analysis: insights from the Integrated Biomarker and Imaging Study (IBIS). International Journal of Cardiovascular Interventions 2005; In press.

54. Hrynchak P, Simpson T. Optical coherence tomography: an introduction to the technique and its use. Optom Vis Sci. 2000;77:347-56.

55. Brezinski ME, Tearney GJ, Bouma BE, Boppart SA, Hee MR, Swanson EA, et al. Imaging of coronary artery microstructure (in vitro) with optical coherence tomography. Am J Cardiol. 1996;77:92-3.

56. Patwari P, Weissman NJ, Boppart SA, Jesser C, Stamper D, Fujimoto JG, et al. Assessment of coronary plaque with optical coherence tomography and high-frequency ultrasound. Am J Cardiol. 2000;85:641-4.

57. Tearney GJ, Jang IK, Kang DH, Aretz HT, Houser SL, Brady TJ, et al. Porcine coronary imaging in vivo by optical coherence tomography. Acta Cardiol. 2000;55:233-7.

58. MacNeill BD, Jang IK, Bouma BE, Iftimia N, Takano M, Yabushita $\mathrm{H}$, et al. Focal and multi-focal plaque macrophage distributions in patients with acute and stable presentations of coronary artery disease. J Am Coll Cardiol. 2004;44:972-9.

59. Jang IK, Tearney GJ, MacNeill B, Takano M, Moselewski F, Iftima $\mathrm{N}$, et al. In vivo characterization of coronary atherosclerotic plaque by use of optical coherence tomography. Circulation. 2005;111:1551-5.

60. Regar E SJ, van der Giessen W, van der Steen AF, Serruys PW. Real-time, in-vivo optical coherence tomography of human coronary arteries using a dedicated imaging wire. Am J Cardiol. 2002;90:129H.

61. Fuster V. Human lesion studies. Ann N Y Acad Sci. 1997;811: 207-24; discussion 224-5.

62. Stefanadis C, Diamantopoulos L, Vlachopoulos C, Tsiamis E, Dernellis J, Toutouzas K, et al. Thermal heterogeneity within human atherosclerotic coronary arteries detected in vivo: A new method of detection by application of a special thermography catheter. Circulation. 1999;99:1965-71.

63. Diamantopoulos L, Liu X, De Scheerder I, Krams R, Li S, Van Cleemput J, et al. The effect of reduced blood-flow on the coronary wall temperature. Are significant lesions suitable for intravascular thermography? Eur Heart J. 2003;24:1788-95. 
64. Thieme T, Wernecke KD, Meyer R, Brandenstein E, Habedank D, Hinz A, et al. Angioscopic evaluation of atherosclerotic plaques: validation by histomorphologic analysis and association with stable and unstable coronary syndromes. J Am Coll Cardiol. 1996;28:1-6.

65. Uchida Y, Nakamura F, Tomaru T, Morita T, Oshima T, Sasaki $\mathrm{T}$, et al. Prediction of acute coronary syndromes by percutaneous coronary angioscopy in patients with stable angina. Am Heart J. 1995;130:195-203.

66. Baraga JJ, Feld MS, Rava RP. In situ optical histochemistry of human artery using near infrared Fourier transform Raman spectroscopy. Proc Natl Acad Sci U S A. 1992;89:3473-7.

67. Romer TJ, Brennan JF 3rd, Fitzmaurice M, Feldstein ML, Deinum G, Myles JL, et al. Histopathology of human coronary atherosclerosis by quantifying its chemical composition with Raman spectroscopy. Circulation. 1998;97:878-85.

68. Schneiderman J WR, Weiss A, Smouha E, Muchnik L, ChenZion M, Golan E, et al. Detection of vulnerable plaques in ex- vivo human aortas with novel intravascular magnetic resonance catheter (abstract). Circulation 2002;Suppl.:657.

69. Schneiderman J WR, Weiss A, Smouha E, Muchnik L, Alexandrowicz G, Chen-Zion M, et al. Vulnerable plaque diagnosis by a self-contained intravascular magnetic resonance imaging probe in ex-vivo human in-situ coronary arteries. J Am Coll Cardiol. $2003 ; 41$.

70. Asakura M, Ueda Y, Yamaguchi O, Adachi T, Hirayama A, Hori $\mathrm{M}$, et al. Extensive development of vulnerable plaques as a pancoronary process in patients with myocardial infarction: an angioscopic study. J Am Coll Cardiol. 2001;37:1284-8.

71. Goldstein JA, Demetriou D, Grines CL, Pica M, Shoukfeh M, O'Neill WW. Multiple complex coronary plaques in patients with acute myocardial infarction. N Engl J Med. 2000;343:91522.

72. Buffon A, Biasucci LM, Liuzzo G, D’Onofrio G, Crea F, Maseri A. Widespread coronary inflammation in unstable angina. N Engl J Med. 2002;347:5-12. 